\title{
PROSES DIGITALISASI NASKAH MELALUI MEDIA FLIPBOOK DIGITAL DI MUSEUM BANDAR CIMANUK
}

\author{
Ute Lies Siti Khadijah $^{1^{*}}$; Lutfi Khoerunnisa ${ }^{2}$; Rully Khaerul Anwar ${ }^{3}$; Ayu Apriani ${ }^{4}$ \\ Perpustakaan dan Sains Informasi/Universitas Padjadjaran
}

Korespondensi:*Ute.lies@unpad.ac.id $\underline{1 \text { lutfi12002@mail.unpad.ac.id }} \underline{\text { rully.khaerul@unpad.ac.id }}$

\begin{abstract}
Indramayu Regency has many ancient manuscripts that contain valuable information. Paper-based manuscripts are very easily damaged. Therefore, it is necessary to preserve ancient manuscripts. Switching to a digital flipbook is considered appropriate because it provides an interface that is similar to the original script. This study aims to describe the importance of preserving the cultural heritage of ancient manuscripts owned by the Bandar Cimanuk Indramayu Museum. Digitization can be an effort to preserve ancient manuscripts. The research used descriptive qualitative method. Data collection through observation, interviews, and documentation study. It is hoped that the research results in the form of flipbook development can be used as an effort to preserve ancient manuscripts that represent, protect, and exceed the physicality of ancient manuscripts. The conclusion of this study is that the ancient Legok Kolot manuscript is the identity and wealth of the Indramayu people, so it needs to be digitized so that the preservation of the script is maintained. The media transfer process at the Bandar Cimanuk Museum goes through three main stages, namely the pre-digitization process, the digitization process, and the post-digitization process. In its process, there are three important things that must be considered, such as source characteristics, product usability, and technological characteristics. The use of digital flipbooks as an effort to preserve ancient manuscripts is considered to protect, represent, and exceed the original ancient manuscripts.
\end{abstract}

Keywords: Ancient manuscripts; Manuscript digitization; Originality of manuscripts.

\begin{abstract}
ABSTRAK
Kabupaten Indramayu memiliki banyak peninggalan naskah kuno yang mengandung nilai informasi. Naskah kuno di Museum Bandar Indramayu ini berbahan dasar kertas dan sangat rentan terhadap kerusakan. Berdasarkan faktor tersebut, digitalisasi naskah kuno sangat penting untuk dilakukan. Dalam penelitian ini, penulis mendeskripsikan mengenai alih media atau bentuk digitalisasi dengan mengubah naskah kuno menjadi flipbook digital. Flipbook digital adalah naskah digital yang sengaja dibuat semirip mungkin dengan bentuk naskah aslinya. Penelitian ini bertujuan menggambarkan mengenai pentingnya digitalisasi untuk menjaga warisan budaya naskah kuno yang dimiliki oleh Museum Bandar Cimanuk Indramayu. Digitalisasi bisa menjadi salah satu upaya untuk melestarikan naskah kuno. Penulis menggunakan metode penelitian kualitatif dengan pendekatan studi kasus. Sedangkan teknik pengumpulan data dilakukan dengan observasi, wawancara, dan studi dokumentasi. Hasil penelitian berupa pengembangan flipbook diharapkan dapat digunakan sebagai salah satu upaya pelestarian naskah kuno yang mewakili, melindungi, dan melebihi fisik dari naskah kuno. Kesimpulan dari penelitian ini ialah naskah kuno di Museum Bandar Indramayu yang merupakan identitas diri dan kekayaan warga Indramayu sangat penting untuk dilakukan digitalisasi, supaya orisinalitas naskah dapat tetap terjaga. Proses digitalisasi di Museum Bandar Cimanuk ini melalui tiga tahapan utama yang pertama persiapan digitalisasi, proses digitalisasi, dan setelah digitalisasi. Dalam kegiatannya terdapat tiga hal penting yang harus diperhatikan seperti karakteristik sumber, kegunaan produk dan karakteristik teknologinya. Penggunaan flipbook digital sebagai upaya pelestarian naskah kuno dinilai dapat melindungi, mewakili, dan melebihi naskah kuno aslinya.
\end{abstract}

Kata Kunci: Naskah kuno; Digitalisasi naskah; Orisinalitas naskah.

\section{PENDAHULUAN}

Naskah kuno merupakan salah satu peninggalan leluhur yang bersifat tertulis menceritakan tentang budaya, kebiasaan, dan adat dari suatu kaum di suatu daerah bahkan suatu bangsa. Berisi tentang pemikiran-pemikiran dan perasaan masyarakat yang ditulis pada masa lampau, naskah kuno memiliki nilai sejarah yang tinggi. "Naskah kuno merupakan hasil tulisan tangan yang berisi 
informasi tentang budaya bangsa yang bernilai penting bagi kebudayaan nasional, sejarah, dan ilmu pengetahuan" (Hendrawati 2014). Naskah di masa lampau kini menjadi benda cagar budaya yang diatur dalam Undang-Undang Nomor 11 Tahun 2010 tentang Cagar Budaya. Seperti yang dikatakan oleh Nugraha (2019) bahwa naskah-naskah kuno adalah warisan budaya bangsa yang memiliki wujud konkret dan dinyatakan sebagai identitas suatu daerah bahkan suatu bangsa. Maka dari itu, sangat penting bagi generasi penerus untuk sadar akan pentingnya keberadaan naskahnaskah kuno.

Di Indonesia, naskah kuno tersebar luas di penjuru Nusantara, salah satu tempat yang banyak menyimpan naskah kuno adalah Museum Bandar Cimanuk. Museum Bandar Cimanuk merupakan museum bersejarah yang terletak di Kabupaten Indramayu. Museum yang didirikan tahun 2015 atas inisiatif para pecinta budaya yang tergabung dalam Yayasan Komunitas Indramayu Historia dan bersinergi dengan pemerintah Kabupaten Indramayu merupakan salah satu museum yang menyimpan peninggalan warisan berupa naskah kuno dari berbagai usia. Naskah kuno yang terdapat di Museum Bandar Cimanuk lebih banyak menceritakan tentang sejarah penyebaran agama Islam di Indramayu. Oleh karena itu, isi dan kandungan informasi yang terdapat di dalam naskah kuno tersebut sangatlah penting dan bernilai karena naskah tersebut mengupas tentang sejarah penyebaran sebuah agama majoritas di daerah yang memiliki ikon bersejarah yang erat kaitannya dengan agama Islam. Dengan adanya naskah kuno tersebut, masyarakat khususnya generasi penerus dapat mengetahui berbagai peninggalan dan sejarah yang dilalui oleh para nenek moyangnya.

Beberapa dari naskah kuno masih disimpan secara perseorangan atau dititipkan kepada orang yang dianggap sesepuh oleh masyarakat. Masih banyak masyarakat yang tabu dan enggan membuka naskah kuno yang mereka miliki karena dianggap keramat. Sayangnya, banyak masyarakat yang kurang mengetahui bagaimana cara merawat naskah kuno dengan baik dan benar. Dalam kesempatan wawancara dengan pengurus museum, pelaksana Museum dan Benda Purbakala Dinas Kebudayaan dan Pariwisata Kabupaten Indramayu, Suparto Agustinus mengatakan bahwa banyak naskah kuno dalam kondisi kurang baik dikarenakan faktor perawatan dan penyimpanan. "Naskah kuno termasuk warisan budaya dan termasuk barang langka, maka perawatannya tentu memerlukan perlakuan khusus agar tetap bisa dijadikan kajian pustaka dan bisa tetap dilestarikan untuk generasi penerus" (Rahman 2019). Terkait dengan hal tersebut, melestarikan bahan pustaka, terutama bahan pustaka yang memiliki nilai sejarah termasuk naskah kuno, pada prinsipnya merupakan upaya pelestarian kekayaan informasi dan warisan bangsa untuk kepentingan jangka panjang. Naskah kuno sering disebut sebagai barang peninggalan yang mudah rusak karena materialnya yang rapuh dan semakin rentan akibat dimakan usia. Oleh karena itu, "Penjagaan dan perawatan yang sangat ekstra perlu diperhatikan sebagai upaya untuk melestarikan naskah kuno agar naskah yang ada masih tetap dapat dinikmati dan informasi yang terkandung di dalamnya dapat sampai kepada generasi penerus bangsa" (Amin 2011).

Merespon hal tersebut, perpustakaan memiliki peran penting sebagai tempat penyimpanan informasi dan terkumpulnya berbagai karya warisan bangsa untuk kepentingan jangka panjang. 'Pelestarian bahan pustaka dapat dikatakan sebagai tabungan sumber informasi, karena bila tidak dilakukan pelestarian bahan pustaka, maka akan menghancurkan kekayaan perpustakaan dan hilangnya informasi, lebih parah lagi akan hilangnya warisan budaya bangsa' (Prastani 2019). Perpustakaan yang pada hakikatnya memainkan peran krusial dalam menjaga dan menyebarkan ilmu pengetahuan, usaha penyimpanan naskah-naskah kuno oleh perpustakaan memungkinkan terpeliharanya budaya masa lalu dan tetap mendapatkan tempat didalam tatanan sosial budaya masyarakat sekarang dan di masa yang akan datang. "Dengan adanya peranan perpustakaan sebagai wadah budaya memungkinkan adanya sebuah mata rantai yang menghubungkan sejarah 
masa lalu dengan masa kini dan pelajaran yang berarti bagi kehidupan masa yang akan datang, maka jelas peranan perpustakaan tak dapat diabaikan." (Nugraha 2019).

Naskah kuno yang ada semakin hari tentunya semakin tidak terawat dan mengalami pelapukan. Faktor perawatan yang minim dan faktor pengetahuan masyarakat masih menjadi hal utama yang harus kita soroti. Sejalan dengan kerusakan yang terjadi, kemajuan teknologi dan informasi menjadi salah satu cara yang efektif untuk tetap melestarikan warisan budaya, diantaranya melalui digitalisasi naskah. Dalam upaya melestarikan informasi yang terkandung dalam naskah kuno, bukanlah menjadi satu hal yang mudah, pasalnya kita harus tetap menjaga keaslian naskah, orisinalitas naskah, bahkan dalam proses digitalisasi tersebut, kita tidak boleh sampai merusak fisik naskah asli. Untuk menanganinya perlu adanya kegiatan pelestarian. Adapun hakikat dari pelestarian naskah kuno adalah upaya untuk mempertahankan usia suatu sumber informasi, "pelestarian naskah kuno merupakan tindakan yang dilakukan seseorang, masyarakat, organisasi atau pemerintah dalam mencegah, memelihara dan mengawetkan naskah kuno" (Khadijah, Rizal, dan Zulfan 2019).

Salah satu upaya yang dapat dilakukan adalah dengan mengalihmediakan naskah kuno menjadi digital. Hendrawati (2014) menyatakan bahwa "proses alih media atau digitalisasi berarti mengubah bentuk dari bahan tercetak ke dalam bentuk digital berupa, microfiche, pita magnetik, CD, DVD dan bentuk lainya”. Alih media seringkali dilakukan pada bahan pustaka yang dinilai memiliki nilai sejarah dan memiliki informasi yang penting, seperti naskah kuno, buku-buku langka atau bahan pustaka yang sudah rapuh. Proses digitalisasi ini diharapkan dapat mengurangi penggunaan akses naskah kuno yang asli sebagai salah satu upaya untuk menghindari kerusakan atau kehilangan naskah, dan di sisi lain dapat memberikan kemudahan akses informasi, tanpa melibatkan naskah aslinya.

Berbicara mengenai versi digital, upaya alih media naskah kuno dapat dilakukan dengan pembuatan flipbook. Istilah flipbook diambil dari sebuah mainan anak-anak yang berisi kumpulan gambar yang berbeda-beda. Cara penggunaannya dengan membalik dari halaman yang satu ke halaman selanjutnya secara cepat sehingga akan memperlihatkan gambar tersebut seakan-akan bergerak. Flipbook memiliki keunggulan daripada buku digital lainnya seperti dapat memberikan efek suara, membalik halaman, bayangan halaman, menambahkan lagu sebagai backsound serta pembuatannya yang relatif mudah. Oleh sebab itu, flipbook cocok digunakan sebagai digital book karena media ini dapat memberikan interface yang mirip dengan naskah aslinya karena menggunakan efek-efek seperti menggunakan buku asli. Selain itu, flipbook mampu mewakili dalam menyajikan informasi mengenai naskah kuno Indramayu. Dengan menggunakan flipbook, informasi yang ada di dalam naskah kuno dapat terlindungi karena dalam menemukan informasi mengenai naskah cukup mengakses naskah tanpa bersentuhan fisik dengan naskahnya" (Erza, Yusup, dan Erwina 2018).

Berdasarkan latar belakang yang dipaparkan di atas, penulis tertarik untuk memaparkan hasil penelitian yang dilakukan oleh penulis mengenai proses digitalisasi atau alih media naskah kuno menjadi naskah digital flipbook. Dengan melakukan proses alih media ini, diharapkan penulis dapat ikut andil dalam upaya pelestarian dan pencegahan kerusakan bahan pustaka berupa naskah kuno. Penulis juga berharap untuk bisa ikut andil dalam melestarikan nilai informasi yang terkandung dalam naskah kuno tersebut dengan memanfaatkan perkembangan teknologi informasi yang memberikan dampak positif untuk Museum Bandar Indramayu. Selain itu, penulis juga berharap, generasi penerus dapat dengan leluasa mengakses peninggalan berupa naskah kuno dengan nyaman, tanpa takut akan terjadi kerusakan pada naskah kuno yang asli. 


\section{TINJAUAN PUSTAKA}

\subsection{Naskah Kuno dan Persebarannya di Indonesia}

Naskah kuno merupakan warisan budaya peninggalan leluhur yang bersifat tertulis menceritakan tentang budaya, kebiasaan, dan adat dari suatu kaum di suatu daerah bahkan suatu bangsa. Berisi tentang pemikiran-pemikiran dan perasaan masyarakat yang ditulis pada masa lampau, naskah kuno memiliki nilai sejarah yang tinggi. Naskah-naskah kuno yang ditulis dalam berbagai bahasa dan aksara memiliki keunikan tersendiri dan memiliki makna tafsir yang beragam, justru menjadi sesuatu hal yang menarik untuk ditelaah. Tulisan-tulisan mengenai politik, agama, kultur, hingga tradisi yang terakumulasi dalam suatu naskah kuno sangatlah penting untuk dipahami sebagai bagian dari ilmu pengetahuan. Sebagaimana yang dikatakan oleh Nugraha (2019) bahwa naskah-naskah kuno adalah warisan budaya bangsa yang memiliki wujud konkret dan dinyatakan sebagai identitas suatu daerah bahkan suatu bangsa. Maka dari itu, sangat penting bagi generasi penerus untuk sadar akan pentingnya keberadaan naskah-naskah kuno.

Dalam penyebarannya, naskah kuno banyak ditemukan di seluruh Nusantara. Hal ini menandakan bahwa Indonesia memiliki banyak keberagaman budaya, sejarah, paham politik, hingga tradisi dan kepercayaan. Di Sumatera Selatan terdapat naskah kuno "Gelumpai" yang ditulis dengan aksara $\mathrm{Ka}-\mathrm{Ga}-\mathrm{Nga}$ merupakan naskah kuno masyarakat Uluan. Naskah yang dibuat sekitar abad ke-16-17 Masehi. diproduksi oleh kalangan ulama Kesultanan Palembang Darussalam menceritakan tentang profil, karakter dan nilai-nilai sosial, serta ajakan dalam merujuk Islam sebagai syariat kehidupan (Ottoman \& Rochmiatun 2020). Naskah ini juga ditafsirkan sebagai bukti dalam penyebaran agama Islam di wilayah Huluan Palembang. Di Sulawesi Tenggara, Kesultanan Buton memiliki banyak naskah kuno yang sudah ada sejak abad ke-16. Naskah kuno yang kebanyakan ditulis dalam bahasa dan aksara Arab ini menceritakan sejarah masuk dan berkembangnya Islam di Sulawesi Tenggara. Menyebrang ke pulau Kalimantan dan Papua, keduanya menghasilkan naskah tertulis yang berjumlah 470 naskah, dan $71 \%$ nya bernuansa Islam (Pudjiastuti 2020). Naskah kuno tersebut ditulis dalam beberapa bahasa, seperti Arab, Melayu, dan Bugis-Makassar. Naskah kuno ini kebanyakan memuat tentang tauhid, shalat, dzikir, aqidah, doa, dan tasawuf (Pudjiastuti 2020). Selain itu, masih banyak naskah kuno lainnya yang tersebar di berbagai daerah di Indonesia, namun kurangnya perhatian dari pemerintah dan kesadaran masyarakat akan keberadaan naskah kuno menjadi tantangan tersendiri untuk menemukan, mempelajari dan melestarikan naskah kuno itu sendiri.

\subsection{Keberadaan Naskah Kuno di Museum Bandar Cimanuk}

Keberadaannya yang langka dan tata cara perawatannya yang tak mudah membuat naskah kuno lebih aman untuk disimpan di tempat cagar budaya, seperti museum. Salah satu museum yang menyimpan naskah kuno adalah Museum Bandar Cimanuk. Museum Bandar cimanuk merupakan museum bersejarah yang terletak di Kabupaten Indramayu. Museum yang didirikan tahun 2015 atas inisiatif para pecinta budaya yang tergabung dalam Yayasan Komunitas Indramayu Historia dan bersinergi dengan pemerintah Kabupaten Indramayu adalah salah satu museum yang menyimpan peninggalan warisan berupa naskah kuno dari berbagai usia.

Naskah kuno yang terdapat di Museum Bandar cimanuk lebih banyak menceritakan tentang sejarah penyebaran agama Islam di Indramayu. Salah satu koleksi yang paling populer adalah naskah kuno Raden Arya Wiralodra. Menurut sejarah, beliau adalah pengembara yang melakukan Babad Alas atau dalam bahasa Indonesia berarti menebang hutan dan beliau mendirikan Padukuhan Cimanuk pada tanggal 7 Oktober 1527 yang kini ditetapkan sebagai hari lahir Indramayu. Banyak pengunjung yang datang untuk melihat secara langsung naskah kuno yang masih berwujud asli dan tersimpan dengan rapih di Museum Bandar Cimanuk. 
Beberapa dari naskah kuno masih disimpan secara perseorangan atau dititipkan kepada orang yang dianggap sesepuh oleh masyarakat. Masih banyak masyarakat yang tabu dan enggan membuka naskah kuno yang mereka miliki karena dianggap keramat. Namun banyak masyarakat yang belum mengetahui penjagaan dan perawatan naskah kuno, sehingga banyak naskah kuno Padahal naskah kuno termasuk warisan budaya dan termasuk barang langka, maka perawatannya tentu memerlukan perlakuan khusus agar tetap bisa dijadikan kajian pustaka dan bisa tetap dilestarikan untuk generasi penerus (Rahman 2019). Dalam kesempatan wawancara dengan pengurus museum, pelaksana Museum dan Benda Purbakala Dinas Kebudayaan dan Pariwisata Kabupaten Indramayu, Suparto Agustinus mengatakan bahwa, banyak naskah kuno dalam kondisi kurang baik dikarenakan faktor perawatan dan penyimpanan. Naskah kuno merupakan warisan peninggalan berharga yang mudah rusak karena materialnya yang rapuh dan semakin rentan akibat dimakan usia. Oleh karena itu, "penjagaan dan perawatan yang sangat ekstra perlu diperhatikan sebagai upaya untuk melestarikan naskah kuno agar naskah yang ada masih tetap dapat dinikmati dan informasi yang terkandung di dalamnya dapat sampai kepada generasi penerus bangsa" (Amin 2011). Maka dari itu, perlu adanya tindakan lanjut untuk merespon isu tersebut. Salah satu upaya yang bisa dilakukan adalah dengan mengalihmediakan naskah kuno ke dalam bentuk digital.

\subsection{Flipbook Sebagai Alih Media Naskah Kuno}

Di era digital ini, banyak kemudahan yang disediakan untuk kemajuan hidup umat manusia, termasuk mendukung upaya pelestarian naskah-naskah kuno. Era ini memungkinkan proses alih media dari bentuk konvensional naskah kuno menjadi media digital (Prasetyo, Setiawan, dan Islamy 2016). Hendrawati (2014) menyatakan bahwa "proses alih media atau digitalisasi berarti mengubah bentuk dari bahan tercetak ke dalam bentuk digital berupa, microfiche, pita magnetik, CD, DVD dan bentuk lainya". Proses ini biasanya dilakukan terhadap warisan peninggalan yang bersifat rentan akan kerusakan dengan harapan dapat mengurangi penggunaan akses naskah kuno yang asli. Dalam upaya melestarikan informasi yang terkandung dalam naskah kuno, bukanlah menjadi satu hal yang mudah, pasalnya kita harus tetap menjaga keaslian naskah, orisinalitas naskah, bahkan dalam proses digitalisasi tersebut, kita tidak boleh sampai merusak fisik naskah asli. "Pelestarian naskah kuno merupakan tindakan yang dilakukan seseorang, masyarakat, organisasi atau pemerintah dalam mencegah, memelihara dan mengawetkan naskah kuno" (Khadijah, Rizal, dan Zulfan 2019).

Berbicara mengenai versi digital, upaya alih media naskah kuno dapat dilakukan dengan pembuatan flipbook. Istilah flipbook diambil dari sebuah mainan anak-anak yang berisi kumpulan gambar yang berbeda-beda. Berbeda dengan media digital lainnya, flipbook memiliki cara penggunaan yang cukup unik, yakni dengan membalik dari halaman yang satu ke halaman selanjutnya secara cepat sehingga akan memperlihatkan gambar tersebut seakan-akan bergerak. Keunggulan flipbook lainnya adalah media ini dapat memberikan efek suara, membalik halaman, bayangan halaman, menambahkan lagu sebagai backsound serta pembuatannya yang relatif mudah. Oleh sebab itu, flipbook cocok digunakan sebagai digital book karena media ini dapat memberikan interface yang mirip dengan naskah aslinya karena menggunakan efek-efek seperti menggunakan buku asli.

Upaya pelestarian dengan metode alih media merupakan salah satu hal yang paling memungkinkan untuk dilakukan oleh para pustakawan. Terkait hal tersebut, sudah banyak naskah kuno yang di alihmediakan untuk mencegah kerusakan dan kemusnahan. Naskah-naskah tersebut diubah ke dalam bentuk digital book yang sangat umum. Meski begitu, tindakan alih media ini memungkinkan output yang lebih menarik. Didukung dengan kemajuan teknologi yang pesat, dan sumber daya manusia yang kreatif dan inovatif, naskah-naskah kuno tersebut bisa diubah bentuk menjadi sesuatu yang lebih menarik. Tidak hanya dalam tampilan, tapi naskah digital tersebut 
memungkinkan untuk menarik minat masyarakat untuk membaca. Berangkat dari gagasan dan isu tersebut, penulis akan mencoba untuk melakukan penelitian menyangkut alih media naskah konvensional menjadi naskah digital berupa flipbook.

\section{METODE}

Penelitian ini menggunakan metode kualitatif dengan desain penelitian tindakan (action research). Penelitian tindakan merupakan bentuk investigasi yang bersifat refleksi partisipatif, kolaboratif dan spiral yang memiliki tujuan untuk melakukan perbaikan sistem, metode, kerja proses, isi, kompetensi, dan situasi. Penelitian tindakan adalah penelitian yang lebih menekankan pada proses pemecahan masalah dan menciptakan kemajuan yang bisa menggunakan pendekatan kualitatif maupun kuantitatif namun tidak ketat sehingga menghasilkan suatu inovasi untuk perubahan kedepannya dalam prosedur kebijakan. Dalam penelitian jenis ini terdapat beberapa tahap yang harus dilakukan oleh penulis, di antaranya: pertama, melakukan diagnosis. Pada tahap ini peneliti akan mengidentifikasi permasalahan-permasalahan mengenai pelestarian naskah kuno yang ada di Museum Bandar Cimanuk. Kedua, merencanakan Tindakan. Setelah mengetahui permasalahan mengenai pelestarian naskah kuno yang ada di Museum Bandar Cimanuk, tahap selanjutnya ialah membuat rencana tindakan. Pada tahap ini, peneliti memahami apa saja permasalahan yang dihadapi oleh Museum Bandar Cimanuk dan berpikir kritis untuk menemukan solusi yang tepat untuk menyelesaikan masalah tersebut. Setelah mengetahui solusi yang tepat, peneliti menentukan rencana-rencana yang tepat untuk membantu pelestarian naskah kuno yang ada di Museum Bandar Cimanuk. Ketiga, melakukan tindakan. Dalam tahap ini rencana yang sudah ditentukan dalam tahap action planning diterapkan dengan harapan permasalahan mengenai pelestarian naskah kuno di Museum Bandar Cimanuk dapat diselesaikan. Keempat, evaluasi. Setelah tahapan sudah dilakukan, peneliti melaksanakan evaluasi terhadap hasil produk dari kegiatan sebelumnya. Dalam evaluasi ini, akan dilakukan oleh ahli filolog dan ahli media terkait dengan alih media naskah kuno. Setelah itu, akan dievaluasi kembali dengan melihat bagaimana penerimaan dari pihak Museum Bandar Cimanuk. Tahapan yang terakhir adalah pembelajaran. Tahap pembelajaran merupakan bagian akhir yaitu dengan melakukan ulasan tahap demi tahap yang sudah dilakukan. Dalam tahapan ini, pembelajaran harus dipelajari perubahan dalam situasi organisasi dievaluasi oleh peneliti dan kemudian merefleksikannya terhadap hasil proyek, yang terlihat akan dilaporkan secara lengkap.

Objek dalam penelitian ini adalah mengenai proses pelestarian orisinalitas warisan budaya yang dilakukan melalui proses digitalisasi naskah menggunakan media flipbook. Penelitian ini dilakukan di Museum Bandar Cimanuk, Indramayu. Teknik pengumpulan data dilakukan melalui kondisi yang alamiah, yang menitikberatkan pada observasi lapangan, wawancara mendalam (indepth interview) dan studi dokumentasi. Dalam studi dokumentasi, dokumen diperlukan sebagai penunjang penelitian untuk menghimpun informasi tambahan dari naskah kuno yang dijadikan sebagai subjek penelitian, dokumen-dokumen yang menjelaskan mengenai preservasi yang dilakukan terhadap naskah kuno dan dokumen yang berkaitan dengan lokasi penelitian. Uji kredibilitas yang dilakukan melalui triangulasi teknik, dimana peneliti menggunakan teknik pengumpulan data yang berbeda kepada sumber yang sama untuk mendapatkan data. Peneliti juga menggunakan observasi partisipatif, wawancara mendalam dan dokumentasi untuk sumber data yang sama secara satu waktu atau serempak. Peneliti memahami, jika tujuan dari triangulasi yang dilakukan oleh peneliti bukan saja mencari kebenaran mengenai suatu fenomena, tetapi lebih menekankan pada pemahaman yang didapatkan peneliti terhadap apa yang sudah ditemukan di lapangan.

Analisis data yang dilakukan meliputi proses reduksi data, dengan cara merangkum dan memfokuskan pada hal-hal penting yang kemudian akan dicari tema dan polanya, sehingga memberikan gambaran yang lebih jelas untuk mempermudah peneliti dalam pengumpulan data 
selanjutnya. Penyajian data juga dilakukan dalam bentuk penguraian singkat menggunakan bagan dan hubungan antar kategori. Tahap terakhir meliputi tahap verifikasi, di mana verifikasi membantu dalam menemukan proses kesimpulan. Kesimpulan awal yang didapatkan masih bersifat sementara dan masih dapat berubah bila tidak ditemui bukti yang kuat yang mendukung pada pengumpulan data selanjutnya. Namun sebaliknya, jika temuan sebelumnya didukung bukti yang valid dan konsisten saat peneliti kembali ke lapangan untuk mengumpulkan data, maka kesimpulan yang didapatkan merupakan kesimpulan yang kredibel.

\section{HASIL DAN PEMBAHASAN}

Pemanfaatan koleksi naskah kuno di Museum Bandar Cimanuk Indramayu yang menyimpan berbagai macam koleksi dan peninggalan bersejarah di masa lalu dapat penulis paparkan mulai dari suasana saat memasuki area pekarangan museum, akan terlihat alat angkut tradisional seperti becak tua dan sepeda ontel. Di bagian dalam museum, terdiri dari beberapa ruangan. Ada ruangan yang khusus memamerkan naskah-naskah kuno, benda-benda pusaka, dan foto-foto bupati di Indramayu. Di lain ruangan, ada berbagai peralatan yang digunakan oleh para petani dan nelayan di masa lalu. Selain itu, ada ruangan khusus yang berisikan alat-alat elektronik yang dinilai kuno dan digunakan di masa lalu seperti telepon, kamera, piano, dan mesin jahit lama. Di dinding-dinding juga dipasang beberapa koleksi uang kuno, foto bangunan tua, kegiatan yang bersejarah dengan nuansa hitam putih serta berbagai lukisan.

Museum Bandar Cimanuk juga mengoleksi naskah kuno yang jumlahnya kurang lebih 100 naskah. Selain itu, masih banyak naskah yang berada di setiap desa yang ada di Indramayu sebagai wujud pengetahuan desa, dalam artian menyimpan berbagai permasalahan serta informasi masa lalu yang ada di dalam naskah. Sebagian besar dari naskah didapatkan dan menjadi milik yayasan karena yayasan membeli, pemberian sukarela dari masyarakat dan hadiah yang berbagai kalangan berikan kepada pihak museum.

Pengunjung yang ingin melihat naskah kuno ini, pihak museum memajangnya dan memperlihatkan naskah tersebut kepada pengunjung. Naskah kuno dipajang dalam sebuah lemari kaca yang bening, sehingga pengunjung dapat melihatnya dengan mudah. Namun, pengunjung biasa tidak dapat menyentuh naskah tersebut secara langsung. Meskipun begitu, pihak museum memberikan deskripsi pada naskahnya. Deskripsi dibuat dan diletakkan dekat dengan naskah kuno, agar pengunjung tetap mengetahui keterangan atau informasi mengenai naskah tersebut tanpa perlu menyentuh naskahnya. Namun, pemberian deskripsi tidak pada semua naskah, hanya beberapa naskah yang diberi deskripsi.

Kondisi naskah kuno yang ada di Museum Bandar Cimanuk sedikit banyak sudah mengalami kerusakan. Pada naskah kuno yang berbahan kertas, kondisi kertasnya ada yang lapuk hingga berserbuk akibat dari pelapukan kertasnya. Beberapa kertas juga ada yang sobek di bagian tengahnya bahkan yang lebih parahnya hingga bolong. Warna kertas juga sudah berubah menjadi coklat serta ada bagian dari naskahnya yang tulisannya sudah tidak bisa dibaca atau bahkan menghilang dikarenakan proses pelapukan.

Bagian dari naskah yang paling rawan lapuk adalah lembaran kertas yang paling terluar dari naskah, karena lembar tersebut yang paling besar terpapar dengan lingkungan sekitar. Sedangkan naskah di bagian dalam, kebanyakan kondisinya masih sangat bagus. Namun ada beberapa naskah yang robek dan bolong di bagian tengah. Walaupun begitu, kondisi kertas di sekitarnya masih sangat bagus dan dapat dibaca. Hanya tulisan yang di sekitar kertas bolong yang agak sulit untuk dibaca. Untuk tingkat kerusakan naskah yang ada di museum, Pak Sadewo mengatakan bahwa "Kalau bicara masalah itu (kerusakan naskah) relatif ya, kalau untuk yang bisa terbaca sekitar 70\%- 75\% karena konteksnya di sini membicarakan untuk menggali isinya." (Sadewo, wawancara, September 30, 2019). 


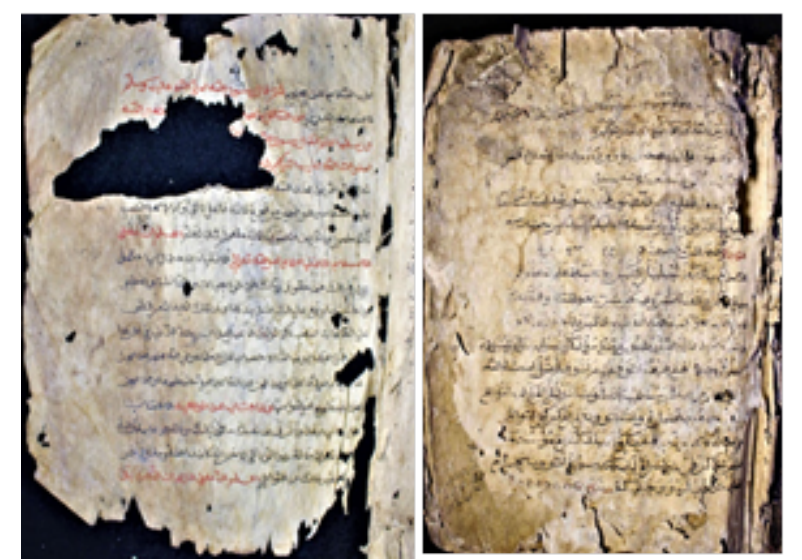

Gambar 1. Lembaran naskah bagian terluar yang rapuh dan bolong

(Sumber: Data Hasil Penelitian 2019)

Dalam melakukan penelitian tindakan akan diawali dengan tahap diagnosis. Diagnosis merupakan proses pemeriksaan terhadap hal-hal yang dipandang tidak beres atau bermasalah. Pada tahap ini peneliti akan mengidentifikasi permasalahan-permasalahan mengenai pelestarian naskah kuno yang ada di Museum bandar Cimanuk.

Pada tahap ini, awalnya peneliti mengidentifikasi bagaimana pengunjung dalam memanfaatkan naskah kuno di Museum Bandar Cimanuk Indramayu, bagaimana pihak Museum Bandar Cimanuk dalam melakukan kegiatan preservasi terhadap naskah kuno yang dimiliki oleh museum, apakah upaya konservasi yang selama ini dilakukan oleh Museum Bandar Cimanuk sudah cukup efektif atau belum, serta mengidentifikasi kebutuhan alih media terhadap naskah kuno di Museum Bandar Cimanuk dan bagaimana kondisi fisik naskah kuno untuk menentukan metode alih media seperti apa yang cocok digunakan dalam melakukan alih media terhadap naskah kuno.

Museum Bandar Cimanuk menyimpan berbagai koleksi naskah kuno dari berbagai daerah, mulai dari Garut, Sumedang dan Indramayu. Naskah kuno yang paling populer di museum ini adalah Naskah Islam Syekh Abdul Manan. Pihak museum memajangnya dan memperlihatkan naskah tersebut kepada pengunjung. Naskah kuno dipajang dalam sebuah lemari kaca yang bening, sehingga pengunjung dapat melihatnya dengan mudah. Namun, pengunjung biasa tidak dapat menyentuh naskah tersebut secara langsung. Walaupun pengunjung tidak dapat menyentuh secara langsung, pihak museum memberikan deskripsi pada naskahnya. Deskripsi dibuat dan diletakkan dekat dengan naskah kuno, agar pengunjung tetap mengetahui keterangan atau informasi mengenai naskah tersebut tanpa perlu menyentuh naskahnya. Namun, pemberian deskripsi tidak semua naskah. Hanya beberapa naskah yang diberi deskripsi.

Naskah kuno yang ada di Museum Bandar Cimanuk kini kondisinya ada yang sudah mengalami kerusakan. Pada naskah kuno yang berbahan kertas, kondisi kertasnya ada yang lapuk hingga berserbuk akibat dari pelapukan kertasnya. Beberapa kertas juga ada yang sobek di bagian tengahnya bahkan yang lebih parahnya hingga bolong. Warna kertas juga sudah berubah menjadi coklat serta ada bagian dari naskahnya yang tulisannya sudah tidak bisa dibaca atau bahkan menghilang dikarenakan proses pelapukan.

Upaya preservasi yang dilakukan Museum Bandar Indramayu untuk saat ini yaitu dengan menyimpan naskah kuno secara profesional seperti menyimpannya di dalam lemari kaca. Untuk penyimpanan dalam lemari kaca, ada naskah yang dipajangkan dan ada naskah yang masih disimpan khusus dalam sebuah kotak oleh pihak museum. Untuk naskah kuno yang dipajang oleh pihak museum, naskah ini dipajang dalam sebuah lemari kaca. Naskah yang disimpan dalam lemari kaca ini yang biasanya dipajang oleh pihak museum dan dapat dilihat langsung oleh 
pengunjung. Lemari kacanya ada dua macam, tipe pertama yaitu lemari kaca yang dibuka dengan cara mengangkat kaca ke atas. Cara yang kedua, lemari kaca yang bisa dibuka dengan cara menggeser kacanya ke samping, seperti membuka lemari.

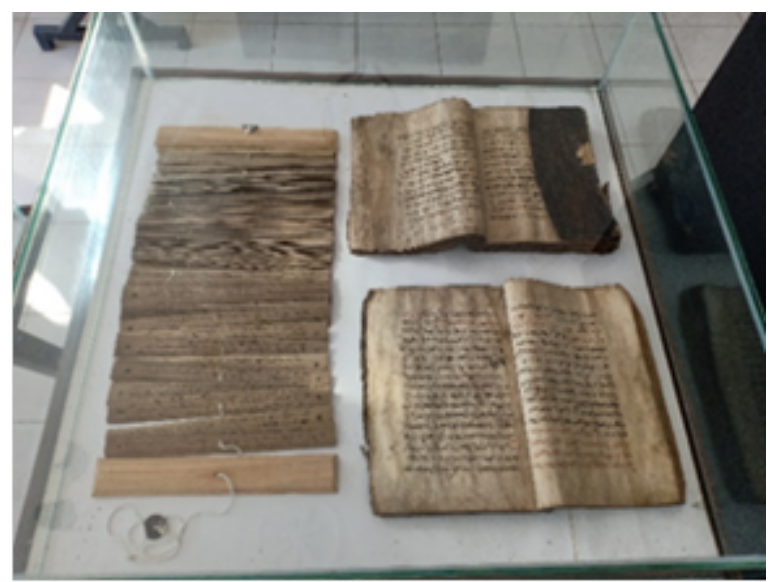

Gambar 2. Tipe lemari kaca yang dibukanya harus diangkat ke atas (Sumber: Data Hasil Penelitian 2019)

Pelaksanaan kegiatan alih media digital ini perlu memiliki satu prosedur khusus pada setiap tahap pelaksanaannya. Hal ini bertujuan, supaya: (1) kegiatan alih media dapat berjalan secara sistematis dan terkontrol, (2) adanya sarana kerja bagi semua pihak dalam melaksanakan kegiatan alih media, yang dapat diadaptasi oleh semua pihak dalam pelaksanaan alih media digital. (3) adanya standarisasi alih media yang dapat diadaptasi oleh semua pihak dalam pelaksanaan kegiatan alih media digital, (4) meningkatkan pengetahuan dan keterampilan mengenai tahapantahapan pelaksanaan kegiatan alih media digital (5) memberikan gambaran mengenai pelaksanaan kegiatan alih media (6) panduan dalam melaksanakan kegiatan alih media digital, baik itu menggunakan metode ataupun teknologi yang digunakan (7) sebagai kualitas kontrol pada proses pembuatan ebook, serta (8) untuk meningkatkan efisiensi pada proses operasionalnya.

Pada kegiatan alih media, peneliti menetapkan alur kerja alih media naskah kuno menjadi flipbook digital berdasarkan (Hendrawati, 2014) yang menjelaskan alur alih media di Perpustakaan Nasional Republik Indonesia. Berdasarkan dari teori tersebut, maka peneliti menentukan bahwa alur dari kerja dari penelitian ini dibagi menjadi tiga tahapan, yaitu: 1. Tahapan pra digitalisasi (prosedur awal) merupakan tahap persiapan sebelum dilaksanakannya proses pengambilan objek digital. Kegiatan pertama yang dipersiapkan adalah lebih bersifat persiapan administrasi, 2. Tahapan digitalisasi merupakan tindakan pengalihan format suatu media ke format digital yang dimulai dengan proses pengambilan objek digital. 3. Tahapan pasca (setelah) digitalisasi, tahapan ini lebih menitikberatkan pada bagaimana objek digital disajikan serta dapat diakses oleh pengguna.

Proses alih media dilakukan dalam berbagai tahapan. Naskah kuno yang akan dialih media perlu melalui tiga tahapan sehingga dapat menghasilkan flipbook digital. Secara garis besar, proses ini dapat digambarkan ke dalam sebagai berikut: 


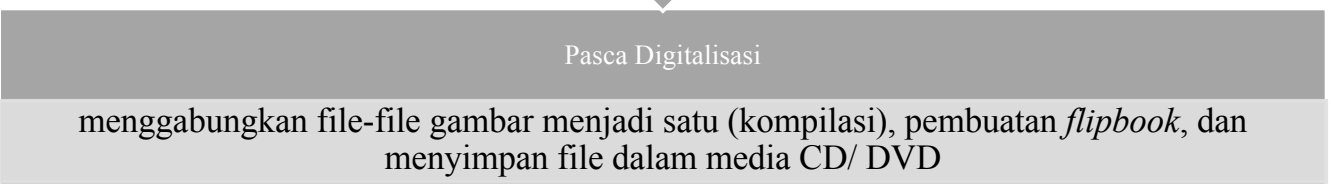

Gambar 3. Bagan proses alih media

Pertama adalah tahapan pra-digitalisasi. Tahap pra-digitalisasi merupakan aktivitas yang dilakukan sebelum melakukan kegiatan pengambilan gambar. Tujuannya ialah mempersiapkan peralatan yang sudah ditentukan sebelumnya serta memastikan kondisi naskah agar siap. Ada dua yang perlu disiapkan dalam proses pra-digitalisasi, yaitu menyiapkan naskah kuno dan menyiapkan alat.

Pada persiapan alat, peneliti akan menyusun alat-alat pada posisinya dan mulai menjalankan software yang digunakan untuk proses scanning. Sedangkan untuk persiapan naskahnya, naskah akan dikondisikan agar mendapatkan semua bagian dari naskah tanpa ada bagian yang terpotong. Selain itu, perbaiki naskah jika ada bagian yang terlipat dan berkeriput.

Kedua adalah tahap digitalisasi, yaitu proses dalam pengambilan foto pada naskah ke dalam bentuk format digital yang dibantu dengan teknologi. Pada proses ini harus dipastikan bahwa hasil digitalisasi naskah dapat dibaca, lembarannya lengkap dan tidak ada bagian yang kurang atau hilang. Di tahap ini juga melakukan proses koreksi dan konveksi dengan software serta mengontrol kualitas untuk memastikan bahwa setiap gambar memenuhi "kesempurnaan". Pasca digitalisasi yaitu proses untuk mengemas produk menjadi hasil akhir. Oleh sebab itu pada proses ini akan dilakukan penggabungan file-file gambar menjadi satu (kompilasi), pembuatan flipbook, dan menyimpan file dalam media CD/ DVD.

Dalam proses pasca digitalisasi ini dilakukan pengambilan gambar (scanning) naskah kuno. Dalam proses scanning ini terjadi pemindahan format dari bentuk tercetak menjadi ke format digital. Kegiatan scanning ini membutuhkan dua orang agar kegiatan digitalisasi berlangsung dengan cepat. Satu orang bertugas untuk membalikkan naskah dan mengatur ketinggian kamera dan lampu lighting, satu orang lainnya bertugas sebagai operator yang memantau live preview, mengatur fitur kamera melalui laptop serta memberi aba-aba untuk membalikkan naskah kepada orang yang lainnya.

Proses scanning naskah kuno dilakukan jika naskah kuno dan peralatan sudah siap untuk digunakan. Proses scanning naskah akan dilakukan dari halaman paling depan, oleh sebab itu perhatikan jenis aksara yang digunakan dalam naskah kuno. Untuk tulisan latin, pallawa dan aksara lainnya dibaca dari kiri ke kanan. Sehingga, pengambilan gambar akan dimulai dari halaman paling kiri menuju halaman paling kanan. Sebaliknya, untuk naskah kuno yang ditulis aksara Arab pegon dimulai dari yang paling kanan dan halaman paling terakhirnya di sebelah kiri. 
Sehingga, proses pengambilan gambar akan dimulai dari gambar yang paling kanan menuju kiri dan seterusnya sampai lembaran terakhir.

Seluruh halaman yang ada di naskah akan dialihmediakan, termasuk halaman naskah yang kosong. Tujuannya agar jumlah halaman dan tampilan digitalnya akan tetap sama dengan dengan fisiknya. Jika ada bagian naskah kosong ditinggalkan, maka akan merubah susunan naskah kuno versi digitalnya. Tentunya ini tidak akan sesuai dengan naskah kuno versi aslinya.

Setiap pengambilan satu gambar naskah, operator akan memeriksa dan memastikan bahwa hasil gambarnya tidak memiliki kekurangan lagi. Jika hasil gambar kurang bagus seperti silau, buram atau kurang terang, operator mengatur melalui laptop atau meminta orang yang memegang naskah untuk mengatur lighting atau kameranya. Gambar yang kurang sempurna akan langsung dihapus dan diambil gambar yang baru. Penghapusan gambar yang kurang sempurna ini meminimalisir adanya file gambar yang ganda. Jika sudah mendapatkan gambar terbaik, operator akan memberi aba-aba untuk membalikkan naskah. Cara ini dinilai sangat efektif dan sangat cepat dalam kegiatan digitalisasi.

Setelah kegiatan pengambilan gambar terhadap seluruh naskah selesai, proses selanjutnya adalah memeriksa seluruh hasil digital, seperti resolusi gambar, ketajaman gambar, kestabilan gambar, kelengkapan jumlah file, memeriksa apakah ada hasil gambar yang terbalik dan sebagainya. Proses pengecekkan file digital tersebut bisa dilakukan langsung menggunakan laptop yang terhubung dengan kamera. Pastikan bahwa seluruh halaman pada naskah yang di scan sudah lengkap tanpa ada yang terlewat. Apabila ada naskah yang buram, perlu dilakukan scanning ulang. Namun apabila hasil digitalisasi naskahnya terbalik, bisa diperbaiki pada tahap editing.

Semua naskah akan tersimpan secara terpisah dalam satu folder sesuai dengan naskahnya. Satu naskah akan tersimpan dalam satu buah folder. Pemisahan naskah ini bertujuan untuk memudahkan dalam pembuatan flipbook agar isinya tidak bercampur dengan naskah lainnya. Atur urutan file gambar naskah dari lembar paling awal hingga paling akhir.

Tahap berikutnya adalah melakukan konversi file digital yang sudah didapatkan. Pada saat pengambilan gambar, format yang akan dipilih adalah format file RAW jika kamera yang digunakan memiliki format RAW. Format ini dinilai paling tepat sebagai master file karena memiliki resolusi tinggi serta dimension image-nya paling besar diantara format file lainnya. Selain master file digital, perlu juga pembuatan file turunan.

Dalam membuat file-file turunan, diperlukan software untuk konversi dari master file digital menuju file turunannya. Namun untuk mendapatkan hasil turunan yang bagus dan tidak merubah warna asli pada format File RAW, lebih direkomendasikan menggunakan software bawaan dari kamera yang digunakan seperti Digital Photo Proffesional.

File format yang digunakan sebagai file turunan dari format file RAW adalah format TIFF 8-bit dengan resolusi 300 dpi. TIFF dipilih karena memiliki kualitas gambar yang baik dibandingkan file turunan lainnya. Format TIFF inilah yang kemudian digunakan untuk proses koreksi gambar (editing image).

Tahapan akhir dalam proses ini adalah kegiatan koreksi, atau editing. Proses koreksi hasil foto berguna untuk menghasilkan gambar yang lebih sempurna dengan bantuan software. Proses koreksi ini tidak akan merubah isi dari gambar serta tidak akan mengurangi maupun menambah jumlah halaman, sehingga semuanya akan seperti naskah aslinya. Proses editing yang dilakukan pada gambar ini ialah untuk pemisahan halaman, kerapihan gambar, konsistensi warna, konsistensi kecerahan, dan penambahan watermark.

Editing menggunakan dua buah software. Software editing yang dipakai untuk kerapihan gambar, konsistensi warna dan kecerahan menggunakan software bawaan dari Windows 10. Cara membuka software editing gambar ini dengan cara klik kanan pada gambar, lalu klik edit with photos. 
Setelah semua bahan sudah selesai didigitalisasi, peneliti kemudian bersiap untuk menyusun hasil digitalisasi menjadi sebuah flipbook digital. Flipbook digital memiliki fitur yang sama dengan buku aslinya, seperti ada efek seperti sedang membuka atau membalik buku per halamannya. Dibandingkan dengan buku versi tercetak, flipbook digital, fitur-fitur yang disediakan di dalamnya juga dinilai lebih lengkap dan lebih menarik daripada naskah aslinya. Fitur-fitur menarik ini seperti tersedianya fitur zoom-in dan zoom-out yang berfungsi untuk memperbesar dan memperkecil gambar, menampilkan nomor halaman, fitur pencarian, dan masih banyak lagi.

Media Flipbook digital dalam upaya pelestarian naskah kuno Islam Syekh Abdul Manan di Museum Bandar Cimanuk Indramayu, penilaian dari pihak praktisi dilakukan oleh Bidang Transformasi Digital di Perpustakaan Nasional Republik Indonesia. Bidang Transformasi Digital mempunyai tugas melaksanakan pelestarian kandungan informasi bahan pustaka melalui alih media digital ke media baru, salah satunya ke media flipbook. Bidang Transformasi Digital menilai bahwa jika flipbook dihasilkan melalui proses alih media dari bahan tercetak seperti naskah kuno, maka flipbook dapat menggantikan atau mewakili fungsi dokumen aslinya dengan cara pemustaka menggali isi informasi yang ada di dalamnya melalui flipbook. Informasi didalamnya sudah lengkap, karena hasil pemotongan naskah sudah bagus sehingga bagian seperti catatan kaki dan catatan tambahan tidak ikut terpotong. Selain itu, saat memperbesar naskahnya, tulisan tidak pecah dan masih jelas untuk dibaca. Watermark juga harus di sebelah kanan dengan opacity dan dan skala yang telah ditentukan, sehingga pengguna dapat fokus membaca konten di dalamnya.

Manfaat secara hakiki, flipbook secara tidak langsung melindungi dokumen asli dari kerusakan fisik, karena dengan tersedianya naskah kuno dalam format flipbook pemustaka tidak perlu membuka atau bersentuhan langsung dengan koleksi aslinya untuk mencari informasi yang terdapat di dalamnya. Namun jika diperlukan dokumen aslinya, cukup disandingkan saja tanpa perlu dibuka lembar per lembar.

File flipbook juga sudah terlindungi sehingga bisa terhindar dari penggandaan dan replika karena sudah menggunakan penanda air (watermark) menggunakan Adobe photoshop sehingga watermark tidak dapat diubah oleh siapapun. Fitur dalam flipbook juga sudah diproteksi sehingga hanya bisa melihat tampilan layarnya tanpa bisa dicetak, disimpan maupun di replika dengan print screen karena watermark yang tidak dapat dihilangkan. Itu artinya dokumen asli juga masih tetap terlindungi. Flipbook juga dinilai memiliki kelebihan dalam hal kemudahan dalam mengakses informasi yang di dalamnya, sehingga tidak perlu repot untuk membuka naskah aslinya yang tersimpan di display. Selain itu, flipbook ini mampu menjaga informasi yang ada di dalam naskah agar tetap lestari dan tidak rusak.

Pihak Museum Bandar Cimanuk menilai bahwa hasil produk dari kegiatan alih media dinilai dapat melindungi informasi yang terkandung di dalam naskah, dapat mewakili fisik naskah serta akses untuk menggunakan naskah menjadi lebih mudah. Museum Bandar Cimanuk menilai bahwa naskah ini nantinya bisa dimanfaatkan dalam upaya untuk melindungi informasi sekaligus fisik naskah karena dengan adanya salinan digital, pihak yang membutuhkan informasi mengenai isinya informasi yang terkandung dapat dengan mengakses tanpa perlu adanya sentuhan langsung dengan naskah fisiknya. Dengan adanya naskah digital ini, Museum Bandar Cimanuk merasa dimudahkan dalam upaya untuk melestarikan fisik dari naskah kuno. Kegiatan alih media ini harus bisa melindungi informasi di dalam naskah sehingga produk digital bisa digunakan untuk menggali informasi tanpa adanya sentuhan langsung yang dapat merusak naskah kuno. Produk digital juga harus dapat mewakili fisik naskah kuno, tidak ada penambahan maupun pengurangan informasi dari naskah aslinya. Terakhir, produk juga harus dibuat dan dikemas ke media yang memudahkan siapa saja untuk mengaksesnya.

Pelestarian terhadap naskah kuno di Museum Bandar Cimanuk hanya berfokus untuk melestarikan naskahnya secara fisik. Oleh sebab itu, salah satu cara dalam rangka pelestarian 
naskah kuno yaitu dengan memanfaatkan teknologi untuk bisa menghasilkan sebuah produk yang dapat membantu pihak museum. Pengembangan naskah kuno yang dikemas digital dalam bentuk flipbook merupakan salah satu cara yang dapat dilakukan untuk melestarikan naskah kuno, flipbook diharapkan bisa mewakili dari naskah kuno itu sendiri. Dengan adanya flipbook, pengguna yang ingin memanfaatkan naskah kuno dapat melihat secara keseluruhan dari isi naskah kuno tanpa menyentuh secara langsung fisik dari naskah kuno. Tentu saja, upaya tersebut dapat menjaga kelestarian naskah kuno dari kerusakan yang diakibatkan oleh tangan manusia namun tetap dapat mengakses isi naskah kuno selengkap mungkin.

Flipbook yang telah dibuat secara tidak langsung melindungi dokumen asli dari kerusakan fisik, karena dengan flipbook pemustaka tidak perlu membuka atau bersentuhan langsung dengan koleksi aslinya dalam mencari informasi. Namun jika diperlukan dokumen aslinya, cukup disandingkan saja tanpa perlu membuka naskah lembar-per lembar.

Produk flipbook dinilai dapat menggantikan atau mewakili fungsi dari dokumen asli, karena dengan penggunaan flipbook pemustaka dapat menggali isi informasi dari naskah kuno tanpa harus menyentuh dan menggunakan file naskah aslinya. Informasi didalamnya sudah lengkap karena lembaran naskah sudah diperbaiki dari lembaran yang terlipat maupun keriput. Bagian penting seperti catatan kaki dan catatan tambahan juga tidak ikut terpotong serta tulisan di naskah saat diperbesar tidak pecah dan masih jelas untuk dibaca.

\section{KESIMPULAN}

Alih media atau digital dirancang sebagai upaya pelestarian terhadap fisik ataupun informasi yang terkandung dalam naskah. Hasilnya tentunya sudah dapat digunakan dengan baik dan sesuai kebutuhan untuk melindungi informasi yang terkandung dalam naskah kuno dan melindungi naskah kuno itu sendiri. Dengan proses digitalisasi yang dilakukan, pemustaka atau pengunjung museum dapat tetap mengakses informasi yang terkandung dalam naskah dengan mengakses flipbook yang ada. Dalam kata lain, flipbook berfungsi untuk mewakilli fisik naskah kuno. Dengan adanya naskah digital, informasi yang terkandung di dalam naskah dapat terlindungi, karena informasi tersebut sudah di backup oleh naskah digital.

Proses alih media memang memerlukan penanganan khusus dan harus melalui tahapantahapan alih media. Proses alih media di Museum Bandar Cimanuk melalui tiga tahapan utama yaitu proses pra-digitalisasi, proses digitalisasi, dan proses pasca-digitalisasi. Dalam proses pradigitalisasi kegiatan yang dilakukan ialah mempersiapkan naskah serta alat-alat yang digunakan dalam kegiatan alih media. Tahap kedua proses digitalisasi dimulai dengan proses pengambilan objek digital, pemeriksaan kembali hasil, konversi file digital menjadi TIFF, koreksi (editing) naskah yang masih memiliki kekurangan dan pengecekan kualitas file. Flipbook memiliki beberapa kelebihan seperti dinilai lebih praktis daripada naskah fisik, tidak banyak memakan ruang, tidak memerlukan perawatan khusus, dapat melindungi fisik naskah kuno, kualitas gambar lebih tinggi, kelebihan visual yang lebih menarik daripada naskah fisik, serta lebih mudah diakses semua orang. Sebaiknya Kegiatan alih media naskah kuno berbasis media flipbook digital terus dilakukan sebagai upaya melestarikan naskah kuno terus dimanfaatkan dan ditingkatkan sehingga semakin maksimal pencapaiannya.

Lembaga pengelola informasi, termasuk salah satunya museum memiliki tugas untuk menjalankan amanat Undang-undang sebagai lembaga yang mempunyai peran penting sebagai penyedia informasi bagi masyarakat. Informasi yang dimaksud juga termasuk informasi yang terkandung dalam koleksi lama yang mengandung informasi. Penulis dapat menarik kesimpulan, bahwa proses alih media memiliki peranan penting dalam pelestarian naskah kuno, mempertahankan keberadaan dan nilai guna dari sebuah dokumen untuk terus dipelihara dan 
dipertahankan dalam jangka waktu yang lama, agar dapat terus dimanfaatkan oleh generasigenerasi penerus di masa mendatang, dengan tanpa mengurangi nilai informasi yang terkandung di dalam sebuat fisik dokumen yang mungkin tersimpan dalam kurun waktu yang sangat lama dan rentan terhadap kerusakan fisik. Dalam penelitian berikutnya, penulis berharap dapat segera melakukan penelitian lanjutan mengenai kebermanfaatan flipbook dalam proses pencarian informasi yang dilakukan oleh para pemustaka atau pengunjung perpustakaan. Mengingat memang, masih banyak masyarakat yang masih belum familiar terhadap penggunaan flipbook ini. Pemanfaatan flipbook di berbagai museum juga memerlukan berbagai perangkat digital lainnya, penulis sangat ingin meneliti lebih lanjut mengenai pemanfaatan dari flipbook ini sendiri ketika sudah dapat diakses secara bebas oleh pengunjung perpustakaan ataupun pengunjung museum.

\section{DAFTAR PUSTAKA}

Amin, Faizal. 2011. "Preservasi Naskah Klasik." Jurnal Khatulistiwa LP2M IAIN Pontianak 1 (1): 89-100.

Erza, Elfitri Kurnia, Pawit M. Yusup, and Wina Erwina. 2018. "Komunikasi Budaya Masyarakat Pandai Sikek Dalam Melakukan Transformasi Pengetahuan Lokal." Jurnal Kajian Informasi Dan Perpustakaan 5 (2): 141. https://doi.org/10.24198/jkip.v5i2.10716.

Fatmawati, Endang. 2018a. "Identifikasi Faktor-Faktor Penyebab Kerusakan Koleksi Perpustakaan." Edulib 7 (2): 108-19. https://doi.org/10.17509/edulib.v7i2.9722.

_. 2018b. "Preservasi, Konservasi Dan Restorasi Bahan Pustaka." Jurnal Libria 10 (1): 13-32.

Hendrawati, Tuty. 2014. Pedoman Pembuatan E-Book Dan Standar Alih Media. Jakarta: Perpustakaan Nasional Republik Indonesia. Jakarta: Perpustakaan Nasional Republik Indonesia.

Khadijah, Ute Lies. Rizal, edwin. Zulfan, Ipit. dkk. 2019. "Identifikasi Faktor Perusak Pada Naskah Kuno Di Situs Kabuyutan Ciburuy Garut.” Journal of Library And Information Sccience 9 (2).

Maryono, Maryono, and Mardi Pramono. 2020. "Pengembangan Website Koleksi Langka Perpustakaan UGM Sebagai Preservasi Digital Heritage Menuju Era Industri 4.0." Jurnal Kajian Informasi \& Perpustakaan 8 (1): 1. https://doi.org/10.24198/jkip.v8i1.23348.

Prastani, intan. Subekti Slamet. 2019. "Digitalisasi Manuskrip Sebagai Upaya Pelestarian Dan Penyelamatan Informasi (Studi Kasus Pada Museum Radya Pustaka Surakarta).” Jurnal Universitas Diponogoro.

Rahman, Handika. 2019. "Wisata Edukasi Di Museum Bandar Cimanuk, Surganya Heritage Indramayu, Tiket Masuk Hanya Rp 5000 Lho!," 2019.

Rustika Chandra. 2016. "Pengembangan Media Buku Cerita Bergambar Flipbook Untuk Peningkatan Hasil Belajar Pada Pembelajaran Ilmu Pengetahuan Sosial." Jurnal Universitas Islam Negeri Malang. 